\title{
THE DEVELOPMENT OF CAUSATION IN OLD ENGLISH AND ITS INTERACTION WITH LEXICAL AND SYNTACTIC DIACHRONIC PROCESSES 1
}

\author{
Javier E. Díaz Vera \\ Universidad de Castilla-La Mancha
}

\begin{abstract}
In this paper I will try to determine some of the different ways the lexically-realized grammatical parameter of causation finds a systematic correspondence on the syntax of Old English verbs, acting as a filter that accepts certain syntactic complementation patterns but blocks others. Furthermore, I will try to show that the strategies used in Old English for the expression of causation can vary from one lexical domain to another. Things being so, the predicates included in the different causative subdomains of a given lexical field will respond to the same lines of lexical development and will show the same syntactic patterns, whereas highly significative differences can be seen between causative predicates from different domains. This way, I want to prove the existence of different 'grammars of causation' in Old English

RESUMEN. En este artículo se intenta determinar algunas de las correspondencias sistemáticas del parámetro gramatical causación con la sintaxis verbal del inglés antiguo, sobre la que actúa como un filtro que permite el uso de determinados parámetros de complementación prohibiendo el de otros. Además, se intentará demostrar que las estrategias usadas en inglés antiguo para expresar el significado causativo pueden variar de un dominio léxico a otro. De esta forma, se observa que los predicados que forman los varios subdominios causativos de un mismo campo semántico responden a idénticas líneas de desarrollo léxico y muestran los mismos patrones sintácticos, mientras que la comparación de verbos causativos de campos diferentes arroja significativas diferencias semánticas y sintácticas. De esta forma, queremos demostrar la existencia de diferentes 'gramáticas de la causación' en inglés antiguo.
\end{abstract}

\section{Introduction}

In this paper I will argue that speakers can express relative measures of causation when expressing a causative action: in other words, I will speak of degrees of causation, and on the different ways these variations in the semantic space are reflected in the verb's syntax (Faber and Mairal 1998b: 37). My first aim will be to

1. This research was carried out within the framework of the project "Diccionario Momasiológico contrastivo de las lenguas germánicas antiguas" funded by the Spanish Ministry of Science and Technology (BFF: 2001-0921). 
determine some of the different ways the lexically-realized grammatical parameter of causation finds a systematic correspondence on the syntax of the Old English ${ }^{2}$ verb, acting as a filter that accepts certain syntactic complementation patterns while blocking others. Moreover, I will try to demonstrate that the strategies used in OE for the expression of causation can vary from one lexical domain to another, i.e. the predicates included in the different causative subdomains of a given lexical field will respond to the same lines of lexical development and will show the same syntactic patterns, whereas highly significative differences (both lexical and syntactic) can be seen between causative predicates from different domains. This way, I want to prove the existence of different 'grammars of causation' in OE, which widely correlate to the different degrees of causativity each predicate can attain.

Obviously, the usual caveats about the nature of the data apply: can the absence of a hypothetically possible meaning or constructions for a given predicate in the whole corpus of $\mathrm{OE}$ written texts arrived to us be taken as a genuine reflection of the semantics/syntax of the verb, or should it be considered accidental? Nevertheless, and in spite of the obvious limitations of historical inquiry, I think that the progressive application of the most recent developments in lexical studies to the analysis and description of the syntactic and semantic relations of the OE verb should greatly contribute to our understanding of this historical variant of the English language.

\section{Lexical causatives in old english: an etymological approach}

Verbs express events or states of being. There is no doubt that a causative situation is semantically relevant to the verb, as it affects the event or state of being directly. As Bybee (1985: 30-33) has recently stated, these causal relationships are often expressed by derivational morphemes. The ModE causation parameter can be signalled by bound morphemes (e.g. darken 'to make dark') or, more frequently, expressed by etymologically unconnected verbs (e.g. die and kill 'to cause to die'), which can however be frequently regularized on purely etymological grounds ${ }^{3}$.

Moreover, many ModE verbs from different lexical domains can be used both as non-causatives and causatives (e.g. dive, shine, shame; Faber and Mairal 1998b: 5357). Once again, the existence in OE of minimal pairs like dúfan - dýfan indicates that

2. The following abbreviations will be henceforward used: IE = Indo-European; L = Latin; Gmc = Germanic; OE = Old English; ME = Middle English; ModE = New English.

3. This is the case of kill, which resulted from the combination of the OE verb cwelan 'die' and the causative suffix Gmc*/-ja-/. After the re-adoption of the Norse verb die during the ME period, OE cwelan became obsolete, and the lexical relationship between the non-causative and the causative subdomains of this lexical domain, which was evident in the OE minimal pair cwelan-cyllan, was overshadowed by the new pair die - kill. 
derivation was by far the most productive source for the expression of causative meanings from non-causatives in Germanic.

\subsection{Grammaticalization and semantic bleaching: $\mathrm{OE}$-jan verbs}

\section{(a) MOVEMENT}

Differently to ModE, the causative pattern was clearly established in the phonological and morphological structure of the different Gmc dialects, where different affixes were systematically used to distinguish between causative and noncausative meanings of the same verb. A first type of derivation is found in the domain of MOVEMENT IN LIQUID: the different Gmc dialects systematically added the formative $* / \mathrm{j} \alpha /$ to an original verbal noun derived from the corresponding noncausative predicate (Nedyalkov and Silnitsky 1978), which explains why none of these verbs has a back root vowel in $\mathrm{OE}$ in the present system (see Table 1).

It should be recalled here that the same $* / j \alpha /$ formative was used in Gmc to derive agents from nouns, e.g. OE hierde 'shepherd' (< Gmc*/herdjoz/, from */herd $\alpha /$ 'herd'), OE déma 'judge' (< Gmc */do:mjoz/, from */do:moz/ 'law' ; Lowe 1972: 214-215). There existed thus a very clear semantic parallelism between both effects of the Gmc formative, so that noun $+* / j \alpha />$ agent noun and verb $+* / j \alpha />$ causative verb. The primary origin of this suffix seems to be in the IE verb */ei-/ (Pokorny 1959-69: 1.293), with the primitive meaning of CAUSATIVE MOTION, as can be seen in the Greek verb $\varepsilon 1 \mu$, with the original meaning 'to put in motion', which came to express 'motion in the future' in Ionian and Attic (Liddell and Scott 1968: 489; cf. OE éode 'I went'). This allows the following reconstruction of the original IE periphrasis (where DIVE1 is used to indicate the intransitive verb 'to dive', and DIVE2 refers to its causative counterpart):

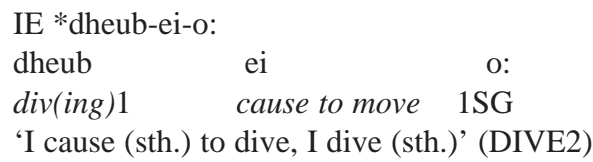

The Gmc system suggests a rather familiar kind of evolution4: if this reconstruction is correct, 'go' was obscured over time and grammaticalized from a lexical verb in composition with a nominal root to an opaque suffix with no semantic content except causation. Significantly, these reconstructed IE periphrases have the

4. As in IE */dho:-/ 'to do' (e.g. IE */dheubeiedhe:si/ > ModE 'you dived'), a lexical verb in origin which became a weak past marker in Gmc (Tops 1978: 359-362). Things being so, one could argue that the two verbal formatives that co-occur in this formidable IE periphrasis (i.e. */-ei-dhe:-/) correspond to the preterite of the defective OE verb gán ('to go'), éode 'I went' (Sievers 1899: §114, Brugmann 18971916: II. 861). 
form of an OV clause 'div(ing) put in motion'5. The original periphrasis is still highly transparent in the Gmc system, as can be seen in Table 1:

\begin{tabular}{|c|c|c|c|c|}
\hline $\begin{array}{l}\text { Gmc VERBAL } \\
\text { INFINITIVE }\end{array}$ & $\begin{array}{r}\text { OE non-causative } \\
\text { (c=ablaut series) }\end{array}$ & $\begin{array}{c}\text { suffixation } \\
\text { (verbal noun }+* /-\mathrm{j} \alpha-/)\end{array}$ & $\begin{array}{l}\text { OE } \\
\text { causative }\end{array}$ & $\begin{array}{c}\text { ModE } \\
\text { (non-causative/causative) }\end{array}$ \\
\hline$* \mathrm{du}: \beta-\alpha-n$ & dúfan (c7) & $\mathrm{INF}^{*} \mathrm{du}: B-+\mathrm{j} \alpha n$ & dýfan & dive 1 /dive2 \\
\hline$* \operatorname{si\eta } k w-\alpha-n$ & sincan $(\mathrm{c} 3)$ & PRET1 ${ }^{*} \operatorname{sa\eta } k w-+j \alpha n$ & sencan & $\sin k 1 / \sin k 2$ \\
\hline${ }^{*}$ deup-ja-n & diopan $(\mathrm{c} 3)$ & PRET1 *daup - +jan & dýppan & - /dip \\
\hline
\end{tabular}

Table 1: OE verbs of MOVEMENT IN LIQUID: the development of the causative subdimension.

The semantic effects of this process can be seen from the following distribution of the causative and non-causative subdimensions of OE verbs of MOVEMENT IN LIQUID (Table 2):

\begin{tabular}{|c|c|}
\hline MOVEMENT IN LIQUID (NON-CAUSATIVE) & MOVEMENT IN LIQUID (CAUSATIVE) \\
\hline dúfan to GO into the water & $\begin{array}{l}\text { to cause somebody/something to GO into the } \\
\text { water }\end{array}$ \\
\hline $\begin{array}{c}\text { sincan to GO slowly downwards below the } \\
\text { surface of the water }\end{array}$ & $\begin{array}{l}\text { to cause somebody/something to GO slowly } \\
\text { downwards below the surface of the water }\end{array}$ \\
\hline \multirow[t]{2}{*}{$\begin{array}{l}\text { to GO deep into a liquid for a short } \\
\text { time }\end{array}$} & $\begin{array}{l}\text { dýppan1 to cause somebody/something to GO deep into } \\
\text { liquid for a short time }\end{array}$ \\
\hline & $\begin{array}{l}\text { dýppan2 to cause someone/smething to GO deeply into } \\
\text { liquid for a short time (in baptism) }\end{array}$ \\
\hline
\end{tabular}

Table 2: OE verbs of MOVEMENT IN LIQUID:

distribution of the causative and non-causative subdimensions.

From a morphological point of view, these causative predicates show all the features that characterize OE heavy root Class I weak verbs (Lass 1994: 166-167), such as the use of the inflexional endings /-d-/ (preterite) and /-ed/ (past participle). Some examples of the four predicates included in the causative subdimension of MOVEMENT IN LIQUID are ${ }^{6}$ :

5. Note also that the internal order of the IE periphrasis */dheub-eie-dhe:-si/ (i.e. ROOTCAUSATIVE-TENSE-PERSON-NUMBER) agrees with Bybee's statistics on the relative positions of verbal prefixes in a wide range of living OV languages (1985: 196-200), and reflects the ancestral word order pattern (a tendency already described by Givón 1979: 239-245).

6. Most of the examples presented in this part of the research have been extracted from the Helsinki Corpus of English Texts. I have maintained the code values used by its compilers (which refer to 'part of corpus', 'prototypical text category', 'text type' and 'abbreviated title') to define the textual parameters (Kytö 1996: 43-60). Examples extracted from the Oxford English Dictionary (OED) are marked with [§]; for uniformity reasons, I have reproduced the codes used in the Helsinki Corpus throughout the paper. 
THE DEVELOPMENT OF CAUSATION IN OLD ENGLISH AND ITS INTERACTION WITH LEXICAL

[1] DÝFAN: Mec feonda sum feore besnypede, woruldstrenga binom, woette sipan, dyfde on watre, dyde eft ponan, sette on sunnan, par ic swipe beleas herum pam pe ic hoefde [lit. 'SOME ENEMY DEPRIVED ME FROM LIFE, TOOK AWAY (MY) STRENGTH, AFTERWARDS IN LIQUID, DIVED (ME) IN WATER, DID THAT AGAIN, PLACED (ME) IN THE SUN, THERE I WAS COMPLETELY DEPRIVED OF THE ARMIES THAT I HAD';OX/3_XX_XX_RIDDL,193].

[2] SENCAN: Ac ondrcedap pone pe pa sawle moeg and eac pone lichaman on helle besencan [lit. 'BUT THEY FEAR THAT THE SOUL MAY, AND WITH IT THE BODY, IN HELL SINK'; O3_IR_RELT_LWSTAN1,80].

[3] DÝPPAN1: Dryge hine ponne on sunnan and dyppe hine opre sypan [lit. 'DRIES HIM THEN IN THE SUN AND DIPS HIM ON THE OTHER SIDE'; O3_IR_RELT_LWSTAN2,172].

[4] DÝPPAN2: Ic eowic depu vel dyppe in wattre in hreunisse sepe ponne cefter me cymep [lit. 'I DIP YOU VERY DEEP IN WATER IN PENITENCE FOR THOSE WHO COME AFTER ME'; O3_XX_NEWT_RUSHW,37].

In the causative subdomain, an agent causes someone or something to go downwards into a liquid; it follows that all these verbs have a transitive use (SVO), whereas the verbs in the non-causative subdomain are one-place predicates which do not (SV). See for example?:

[5] DÚFAN: Ic...deaf under ype [lit. 'I...DOVE UNDER THE WAVE'; [§]OX/3_XX_XX_RIDDL,73].

[6] SINCAN: Geseah pa pone wind swipne frohtade \& pa ingon sincan cegde cwepende 'Hol mec drihten' [lit. 'THEN HE SAW THE STRONG WIND AND HE WAS SCARED AND THEN BEGAN TO SINK SAYING 'SAVE ME, LORD'; O3_XX_NEWT_RUSHW,125].

[7] DÍOPAN: per waxep wunde \& deopep into be soule [lit. 'THERE THEY WASH THE WOUNDS AND DIP INTO THE SOUL'; [\$]M1_IR_RELT_ANCR,288].

\section{(b) PHYSICAL PERCEPTION}

Predicates expressing PHYSICAL PERCEPTION represent a further example of derivation as a source of causation. In this case, the suffix $\mathrm{Gmc} * / \mathrm{j} \alpha /$ is added to a nominal root (which generally refers to a part of the human body) to express the

7. The OED gives the following example of OE díopan used transitively: We cwadon be Jam blaserum, pat man dypte pone ap be pryfealdum [lit. 'We said about the incendiaries that the oath was dipped thrice'; [\$]O3_IR_RELT_LWSTAN6]. Obviously, the form dypte corresponds to the weak preterite of dýppan, not of díopan, which functions as a strong verb in OE (preterite déop). 
approximate meaning ' $\mathrm{X}$ (a person) causes $\mathrm{Y}$ (a part of his body) to perceive something by moving', as in IE */pe:leio:/ 'I touch':

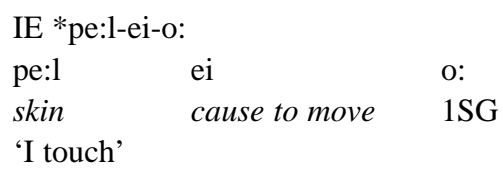

Numerous examples of this process of noun-verb derivation can be found in the different subdomains of PHYSICAL PERCEPTION8, e.g.:

HEARING: Gmc */ $\alpha$ uzon/ 'ear' (OE éare) > Gmc */h $\alpha$ uz jon/ 'to cause someone's ears to PERCEIVE something' (OE híeran 'to hear')

SMELL: Gmc */noso:/ 'nose' (OE nosu) > Gmc */nosjon/ 'to cause someone's nose to PERCEIVE something' (OE */næsian/ > ME neose)

TOUCH: Gmc */fo:1/ 'hand' (OE folm; cf. L pellis 'skin') > Gmc */fo:ljon/ 'to cause someone's hand/skin to PERCEIVE something' (OE félan)

TASTE: Gmc */beukoz/ 'the central part of the trunk' (OE búc 'stomach'; cf. Frankish búk 'belly, trunk') > Gmc */bheurjon/ 'to cause someone's stomach to PERCEIVE something' (OE byrgan 'to taste, eat')

\section{(c) FEELING and EMOTION}

Broadly speaking, the development of causative predicates of FEELING follows the same evolutive pattern as those of PERCEPTION. However, when a concrete physical organ is selected as the see of a given feeling, this is usually internal. The HEART (Gmc */herton-/ > OE heorte) is seen in most IE languages as the locus of such different things as memory (e.g. ModE 'to learn by heart'), love (e.g. ModE 'sweetheart') or sincerity (e.g. ModE 'heart-to-heart'). The most general metaphorical sense of this word in the different Old Gmc dialects was that of courage (as in ModE 'to lose heart'), as can be seen from their lexicalization of the causative Gmc

8. I have not been able to find a correspondence between IE words for visual organs and for vision. Only in the case of IE */okw-/ 'eye' (found with taboo deformation in Gmc */ougo:n-/ > OE éage; Pokorny 1959-69: 775) and the originally causative Gmc */sk $\alpha$ uwoj $\alpha \mathrm{n} /$ 'to cause someone's eyes to PERCEIVE something' (OE scéawian 'to look'; from IE */keu-/; Pokorny 1959-69: 587), some degree of phonetic similitude can be detected. 
*/hertjon/ (OE hiertan) with the meaning 'to cause oneself or someone else to FEEL courage':

[8] Mid oprum worde he hierte [lit. 'WITH OTHER WORDS HE ENCOURAGED (THEM)'; [§]O2_IR_RELT_CP,53)

Words for LIVER (Gmc */lißro/ > OE lifer) present the same consonantism found in the originally causative predicates leave ( $\mathrm{Gmc} * / \operatorname{loi} \beta \mathrm{j} \alpha \mathrm{n} />\mathrm{OE}$ lafan 'to cause oneself to STAY [prot. alive]') and love (Gmc */lußo:jon/ > OE lufian 'to cause oneself to FEEL affection'9), corresponding to the ancient notions that the liver was the see of live (coupled with BRAIN and HEART) and of love and violent passion. OE books of medicine (both scientific and popular) are full of references to the importance of this vital organ, e.g.:

[9] Gif se geswollena mon on pare lifre oppe se apundena swa aswollen gebit op pone fif \& twentige pan daeg swa se swile ne berstep ponne onginp sio lifer heardian, gif hio gebyrst ponne bip par wind on pare lifre [lit. 'IF THE SWOLLEN MAN IN THE LIVER REMAINS THUS SWOLLEN FOR TWENTY-FIFE DAYS AND THE SWELLING DOES NOT STOP THEN STARTS THE LIVER TO HARDEN, IF THIS HAPPENS THEN THE AIR GETS INTO THE LIVER'; O2_IS_HANDM_LAECEB,200].

However, direct references to the LIVER as the see of FEELINGS and EMOTIONS are not found until the ME period:

[10] The livere makth him forto love [lit. 'THE LIVER MAKES HIM TO LOVE'; [§]M3_NI_FICT_GOWER,3].

Finally, the Gmc word for TRUNK */li:kom/ (as opposed to the LIMBS, Gmc */limom/) can be seen as the basis of Gmc */li:ko:jon/ 'to cause oneself to FEEL pleasure' (> OE lícian 'to like'):

[11] Sua eac Dauit, pe folneah on eallum pingum Gode licode [lit. 'So ALSO DAVD, WHO IN EVERY THING GOD PLEASED'; O2_IR_RELT_CP,35].

9. Differently to the other weak verbs analysed here, OE lufian corresponds to the so-called Class II, which is formed by deverbal and denominal predicates with what is sometimes called an intensive sense (e.g. OE lócian 'to see intensively, to look'). From a chronological point of view, these verbs are relatively newer than those belonging to Class $\mathbf{I}$, as can be seen from the absence of $i$-umlaut on the verbal root (Görlach 1997: 84). In the concrete case of OE lufian, the existence of the Class I verb lifan 'live' (also found as libban and leofian; see Bosworth and Toller, 1898) can account for its verbal class. Finally, note that in Swahili (Perrott 1987: 120-123) the same morpheme (isha/iza) is used to express both causative and intensive meanings. 
Causative predicates expressing more abstract EMOTIONS (such as sadness, happiness, shame or pleasure), for which no clear identification with a bodily organ existed, were generally derived directly from the noun given to that feeling, so that:

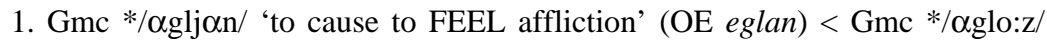
'sadness' (found only in Gothic aglo; cf. OE egle 'loathsome').

2. Gmc */lustjon/ 'to cause to FEEL pleasure' (OE lystan) < Gmc */lustuz/ 'pleasure' (ME lust).

3. Gmc */skomjon/ 'to cause to FEEL shame' (OE scéamian) < Gmc */skomo/ 'shame' (OE sсеати).

4. Gmc */hrewwjon/ 'to cause to FEEL regret' (OE hréowian) < Gmc*/hrewo/ 'regret' (OE hréow).

The case of Gmc */hrewwjon/ is especially interesting, since the corresponding OE weak verb hréowian (which is found exclusively in Northumbrian texts) soon developed the new non-causative meaning 'to show SORROW' (i.e. 'to repent'):

[12] Hreowigas \& gelefes to godspell [lit. 'REPENT AND RESPECT THE GOSPELs'; [\$] O3_XX_NEWT_LIND, 15].

The existence in WGmc of a parallel impersonal predicate, OE hréowan (strong C7), formed by zero-derivation from the above mentioned noun $\mathrm{Gmc} * / \mathrm{hrew} \alpha$ /'regret', to express the meaning 'to cause SORROW' (Bosworth and Toller, 1898), is to be taken as one of the factors that permitted this semantic change from causative to noncausative. The development of the OE predicate hréowan is thus exceptional: whereas from a diachronic point of view this verb is not the result of the addition of the causative suffix $* / j \alpha /$, sincronically speaking it constitutes a 'rare' example of strong causative. This exceptionality can however be explained by the fact that the OE predicate of FEELING hréowan has its primary origin in the IE verb of MOVEMENT */kreu-/ 'to push' (Pokorny 1959-69: 622), from where it has developed directly through metaphorical extension (as in the different metaphorical senses of ModE 'to move').

[13] Mec hreowep pas mengu pe hie vel forpon preo dagas is [lit. 'I AM SORROW FOR THE CROWD. THAT IT IS WELL FOR THREE DAYS'; O3_XX_NEWT_RUSHW,131].

\section{(d) COGNITION}

There existed finally a wide group of OE denominal verbs of COGNITION derived from this causative pattern. Obviously, most of the nouns from which these verbs are derived make reference to the MIND, the see of cognition. One example can be found in the impersonal verb OE pyncan, which is one of the multiple results of an intricate process of derivation ${ }^{10}$, through which the zero-grade of the IE nominal root

10. The originally causative OE pencan 'think' and the intensive OE pancian 'thank' are other denominal verbs derived from this IE root. 
*/tong-/ 'thought' (Gmc */ punk-/; Pokorny 1959-69: 1.1088) developed into the

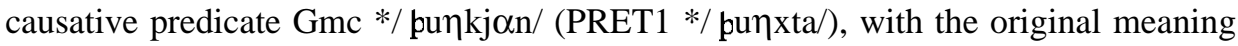
'to cause someone's thought to KNOW a quality of something'.

[14] Philippuse gepuhte after pam pat he an land ne mehte parm folce mid gifan gecweman be him an simbel weron mid winnende [lit. 'PHILIPUS THOUGHT THEREAFTER THAT HE IN ONE COUNTRY COULD NOT PLEASE WITH GIFTS THE FOLK THAT ALWAYS HAD THE VICTORY ON HIM'; O2_NN_HIST_OROS,116].

[15] Do swa be pynce, fyrngidda frod, gif pu frugnen sie on wera corpre [lit. 'Do AS YOL' THINK, PROVERBIAL WISDOM, IF YOU WERE ASKED ON THE COMPANY OF MEN': OX/3_XX_XX_ELENE,81].

Note the phonological correspondence of this root with IE */tang-/, nasalized form of */tag-/ 'touch' (OE paccian 'caress', L tangere 'touch'; Pokorny 1959-69: 1054). Following the general lines described by Sweetser in her Mind-as-Body Metaphor (1990: 27-37), I will temptatively claim the possibility that OE pyncan may be treated as a metaphorical extension of the original predicate of sense-perception, as a result of the following succesion of semantic changes:

TO TOUCH (IE */tang-/: non-causative; physical)

$>$ [1] TO BE TOUCHED (OE me pyncp: causative; mental)

$>$ [2] TO TOUCH (ModE I think: non-causative; mental)

The IE root */men-/ 'mind', which is found in Gmc with two different types of vocalism, was the basis for the development of the different causative subdomains of remembering (i.e. 'to cause oneself/someone else to THINK about something of the past). On the one hand, Gmc */mun-/ (found in the the non-causative OE gemunan 'to remember'; cfr. L memini) becomes Gmc */mynan/ 'to cause to REMEMBER', from where OE gemynan 'remind' and, by further affixation, the denominal Class II weak verbs mynegian 'to bring to one's mind' and gemynegian 'to call to mind'. A similar process is found in OE Class II gemyndigian 'to remember, to call to mind', derived from the nominal root $\mathrm{OE}$ gemynd 'memory'.

[16] GEMYNAN: Gemyne pcet pu gehalgige pone roestedceg [lit. 'REMEMBER THAT YOU CONSECRATE THE DAY OF REST'; O2_STA_LAW_ALFLAWIN,26].

[17] MYNEGIAN: Ure drihten celmihtig god us singalice mynegap purh his halgan bec mid pam gastlicum wordum, pe he sylf mid his mupe bebead [lit. 'OUR LORD ALMIGHTY GOD US ALWAYS REMINDS THROUGH HIS HOLY BOOKS WITH THE SPIRITUAL WORDS, THAT HE HIMSELF WITH HIS MOUTH PRAYED'; O3/4_IR_HOM_SUND6,164].

[18] GEMYNEGIAN: Godes gast woron onwrigene pa Godes gepeahtas, hu gesproec he afer pcet, pe ic bufan gemynegode [lit. 'BY GOD'S SPIRIT WERE REVEALED GOD'S THOUGHTS, HOW HE SPOKE ABOUT THAT, THAT I REMINDED ABOVE'; O2/3_NN_BIL_GDH,137]. 
[19] GEMYNDIGIAN: ...to doenne miltheortnise mip fadorum \& gemyndga cypnise [lit '...TO DO MERCY WITH THE FATHERS, AND REMEMBER THE TESTAMENTS': O3_XX_NEWT_LIND,27].

On the other hand, the Gmc noun */mon-/ can also be combined with the causative suffix $* / j \alpha /$, deriving into OE manian 'to bring to mind' and gemanian 'to remind'; cfr. L moneo 'to cause s.o. to think about/to remember something'.

[20] MANIAN: Gif we mid rican mannan hwat embe ure neode manian willap, pat we ne gedyrstlaceat butan mid micelre eapmodnesse [lit. 'IF WE WITH RICH PEOPLE WANT TO REMEMBER WHAT WE DO NOT PRESUME BUT WITH MUCH HUMLITY'; O3_IR_RULE_BENEDOE,45].

[21] GEMANIAN: On pon he us bysene onstealde pat nanig mon ne sceal lufian ne ne geman his gesibbes [lit. 'ABOUT THAT HE GAVE US THE EXAMPLE THAT NO ONE SHALL LOVE NOR REMEMBER HIS RELATIVE'; O2/3_IR_HOM_BLICK2,23].

In Table 3 I propose a reconstruction of the paradigmatic axis of the complete subdimension 'to THINK about something from the past' in $\mathrm{OE}^{11}$ :

\begin{tabular}{|c|c|c|c|}
\hline \multicolumn{2}{|c|}{ REMEMBERING (NON-CAUSATIVE) } & \multicolumn{2}{|c|}{ REMEMBERING (CAUSATIVE) } \\
\hline gemunan & $\begin{array}{l}\text { to THINK about something } \\
\text { from the past }\end{array}$ & gemynan & $\begin{array}{l}\text { to cause someone to THINK about } \\
\text { something from the past }\end{array}$ \\
\hline \multirow[t]{5}{*}{ ofmunan } & $\begin{array}{l}\text { to REMEMBER something of the } \\
\text { remote past }\end{array}$ & mynegian & $\begin{array}{l}\text { to cause someone to REMEMBER } \\
\text { for some reason }\end{array}$ \\
\hline & & gemynegian & $\begin{array}{l}\text { to cause someone to REMEMBER } \\
\text { something for some reason by } \\
\text { using words }\end{array}$ \\
\hline & & gemyndigian & $\begin{array}{l}\text { to cause someone to REMEMBER } \\
\text { for some reason the memory of } \\
\text { something }\end{array}$ \\
\hline & & manian & $\begin{array}{l}\text { to cause someone to REMEMBER } \\
\text { something that is hard to } \\
\text { remember }\end{array}$ \\
\hline & & gemanian & $\begin{array}{l}\text { to cause someone to REMEMBER } \\
\text { something of the remote past that } \\
\text { is hard to remember }\end{array}$ \\
\hline
\end{tabular}

Table 3: OE verbs of REMEMBERING: distribution of the causative and non-causative subdimensions.

11. I do not include here OE mymerian 'to commemorate', found in [22] Pater noster \& credan mymerian $p a$ yldran [lit. 'THE LORD's PRAYER AND THE CREed COMMEMORATE THE Old ONES'; O3_IR_HOM_WULF10C,209), which is an early loanword from L memorare 'to bring to someone's memory' (Souter et al. 1968: 867) 
Differently to thought (IE */tang-/; cf. OE pyncan), the mind (IE */men-/; cf. OE munan) was frequently situated in a concrete physical organ, such as the HEART or the BRAIN12. Our evidence from OE and other Gmc dialects seems to indicate that whereas memory (as well as the other mental activities derived from IE */men-/, which were generally related to knowledge representation) were once considered by ancient Indoeuropeans as functions of concrete body organs (in the same way as PHYSICAL PERCEPTION), whereas general thinking (from IE */tang-/) was metaphorically mapped on the more abstract area of FEELING ${ }^{13}$, so that:

$\begin{array}{lll}\text { (1) } \text { PERCEPTION } & > & \begin{array}{l}\text { knowledge } \\ \text { (e.g. see }>\text { know })\end{array} \\ \text { (2) FEELING } & > & \begin{array}{l}\text { thinking } \\ \text { (e.g. feel }>\text { think) }\end{array}\end{array}$

\subsection{Causation and word-formation: OE ge-causatives}

\section{(a) LIGHT:}

The OE prefix $g e$ - (from $\mathrm{Gmc} * / g \alpha-/$, the etymological equivalent to L con-) is one of the most productive bound morphemes found in the Anglo-Saxon vocabulary (Lass 1994: 204). In many instances the meaning of this prefix is idiosyncratic; however, when added to non-participial verbal roots, the resulting ge-verbs frequently denotes such notions as 'perfectivity' and 'result', often in connection with transivisation of the corresponding intransitive simplex (Kastovsky 1992: 380).

This is the case of prefixed verbs of LIGHT, which can be interpreted as 'a light vehicle (e.g. a jewel, a piece of metal) gives off LIGHT as a result of contact with the beam emitted from a light source (e.g. the sun, a fire, a lamp)', or more simply 'a light source causes a light vehicle to SHINE'. Obviously, the semantic roles of agent and goal are highly restricted by the limited number of possible light sources and vehicles found in the physical world. However, this basic schema is frequently extended "so as to allow its shape to be filled by entities that are not strictly physical or spatial in the prototypical senses" (Faber and Pérez 1993: 131) producing a large number of metaphorical extensions of the basic meaning. The semantic distribution of the most frequently recorded OE predicates expressing LIGHT can be represented as follows:

12. That the physical see of cognition was a controversial matter can be clearly seen in Greek Philosophy: thus, whereas Plato situated most mental activities in the BRAIN, Aristotle favoured the HEART.

13. For a full account of the semantic extensions that relate PERCEPTION to COGNITION in ModE and in other IE languages see Sweetser (1990: § 2). 


\begin{tabular}{|c|c|c|c|}
\hline \multicolumn{2}{|c|}{ LIGHT (NON-CAUSATIVE) } & \multicolumn{2}{|c|}{ LIGHT (CAUSATIVE) } \\
\hline scínan & to give off LIGHT/to be BRIGHT & gescinan & $\begin{array}{l}\text { to cause something to give off } \\
\text { LIGHT/to be BRIGHT }\end{array}$ \\
\hline bierhtan & to SHINE bright & gebierhtan & $\begin{array}{l}\text { to cause something to SHINE } \\
\text { bright }\end{array}$ \\
\hline beorhtian & to become BRIGHT & gebeorhtnian & $\begin{array}{l}\text { to cause something to become } \\
\text { BRIGHT }\end{array}$ \\
\hline glówan & $\begin{array}{l}\text { to SHINE with a sudden, } \\
\text { bright light }\end{array}$ & & \\
\hline twinclian & $\begin{array}{l}\text { to SHINE with intermittent } \\
\text { light }\end{array}$ & & \\
\hline scymrian & $\begin{array}{l}\text { to SHINE with a tremulous or } \\
\text { flickering light }\end{array}$ & & \\
\hline lihtan & to begin to SHINE & & \\
\hline glisian & $\begin{array}{l}\text { to SHINE with a brilliant but } \\
\text { broken and tremulous light }\end{array}$ & & \\
\hline glisnian & $\begin{array}{l}\text { to SHINE with a fitful } \\
\text { twinkling light }\end{array}$ & & \\
\hline glittenian & to SHINE brightly (metal) & & \\
\hline
\end{tabular}

Table 3: OE verbs of LIGHT: distribution of the causative and non-causative subdimensions.

As in modern languages such as ModE or Spanish (Faber and Pérez 1993: 120122), the OE domain of LIGHT is characterized by the existence of a large number of non-causative predicates, in clear contrast to the causative subdomain ${ }^{14}$, with only three verbs: gescinan, gebierhtan and gebeorhtnian. Some of the uses of these OE causative predicates of LIGHT can be illustrated as follows:

[23] GESCINAN: Swa eac se mona, swa miclum he lyht swa sio sunne hine gescinp [lit. 'SO AS THE MOON, WHICH LIGHTS AS INTENSELY AS THE SUN MAKES IT SHINE'; O2_XX_PHILO_BOETHAL,86].

[24] GEBIERHTAN: Swa swa ealle steorran weorpap onlihte \& gebirhte of pare sunnan, sume peah beorhtor, sume unbeorhtor [lit. 'AS ALL THE STARS ARE LIGHTED AND MADE BRIGHT BY THE SUN, BUT SOME MORE BRIGHLY, SOME LESS BRIGHTLY'; O2 XX PHILO BOETHAL,86].

14. This uneven balance between both subdomains can be related to the fact that LIGHT is prototypically emitted from a natural source (such as the sun, a fire or the stars) in a completely natural way (Faber and Mairal 1998b: 54). Only when the beam of light emitted by these primary light agents encounters a medium (i.e. a vehicle to reflect light, such as a metal or a jewel), the general idea of causation can be made possible. 
[25] GEBEORHTNIAN: God geberhtnade hine on hine seolfne [lit. 'GOD MADE HIM BRIGHT ON HIMSELF'; [\$]O3_XX-NEWT_LIND,32].

\section{(b) COMING TO EXISTENCE}

As in the case of verbs of LIGHT, where a natural force acts as cause, the OE causative predicate of EXISTENCE gelimpan 'to happen (to someone)' has been formed by adding the prefix $g e$ - to the corresponding non-causative simplex, $\mathrm{OE}$ limpan 'belong to, pertain' (prototypically used with non-human participants), with the resulting primary meaning of 'to cause someone to start to HAVE something in his perception':

[26] Sum sare angeald afenrceste, swa him ful oft gelamp, sippan goldsele Grendel warode, unriht afnde, op pact ende becwom, swylt after synnum [lit. 'SOME OF THEM GRIEVOUSLY PAID FOR THE EVENING REST, AS IT VERY OFTEN HAPPENED TO THEM, SINCE GRENDEL HAD OCCUPIED THE GOLD-HALL, THAT HE CARRIED OUT UNRIGHT UNTIL THE END ARRIVED, DEATH FOR THEIR SINS'; OX/3_XX_XX_BEOW,39].

[27] Ful earhlice laga \& scandlice nydgyld purh Godes yrre us syn gemane, understande se pe cunne, \& fela ungelimpa gelimpp pysse peode oft \& gelome [lit. 'VERY BAD LAWS AND INFAMOUS TRIBUTES THROUGH GOD'S ANGER ARE COMMON TO US, HE WHO CAN UNDERSTAND IT, AND MANY MISFORTUNES HAPPEN TO THIS FOLK OFTEN AND FREQUENTLY'; O3_IR_HOM_WULF20,271].

That COMING TO EXISTENCE was often expressed in terms of POSSESSION can also be seen from the analysis of the origin of the two hyponyms in the causative subdimension governed by OE gelimpan, the impersonal predicates gebyrian 'to occur, happen' (corresponding to the OE non-causative byrian 'to HAVE need of something') and geweorpan 'to come into being' (from non-causative OE weorpan 'to start to HAVE/to GAIN a new quality, to become', which was probably related to OE weorp, a noun meaning both 'pecuniary value' and 'honour'). Moreover, both causative EXISTENCE and causative POSSESSION were expressed in OE through the bound morpheme ge-(e.g. OE gebyrian, gerisan and gedafnian), as we shall see in the next section.

\section{(c) POSSESSION}

Connections between POSSESSION and EXISTENCE affect also the way noncausative predicates from both domains express their causative meanings. As in the case of EXISTENCE, verbs denoting 'to cause someone to HAVE something' are frequently the result of ge-derivation. The $\mathrm{OE}$ impersonal gebyrian 'to cause to HAVE 
need of something' is used both as a predicate of EXISTENCE (see above) and of POSSESSION (Elmer 1981: 65-66), whereas gerisan 'befit' (from OE rísan 'to ACQUIRE something') and gedafnian 'to be fitting' (from OE dafnian 'to ACQUIRE a quality of something').

Furthermore, ModE expresions like to give birth, to give place or to give way to demonstrate that the lexical subdimension 'to cause someone/something to start to EXIST' acts as an extension of the causative subdomain of POSSESSION, governed by the predicate to give, i.e. 'to make another the recipient of something' 15 , so that COMING TO EXISTENCE is expressed in terms of being given. The same can be said of causative verbs of LIGHT (see above), where light is seen as a quality acquired from a natural light source.

\section{A syntactic characterization of oe etymological causatives}

In the preceding section I have presented an analysis of the process of development of a wide group of OE predicates from different causative subdimenions of the domains of MOVEMENT, POSSESSION, PERCEPTION, LIGHT, EXISTENCE, COGNITION, FEELING and EMOTION. The etymological and semantic analysis of these predicates indicates the existence of parallel diachronic tendencies within each lexical domain, so that (1) the derivation of the different predicates that formed a given causative subdomain shows a high degree of intrafield cohesion, and (2) the metaphorical extensions of these predicates respond to an unitary diachronic trend, characterized by a systematic increase in the degree of abstractness (Sweetser 1990: 25).

It has been argued that verbal predicates from the domain of MOVEMENT represent the most prototypical instantiations of the grammatical category of verb (Givón 1984; Langacker 1987), as they correspond to the highest degree of verbal concreteness (Mairal 1994, Faber and Mairal 1998a). This implies that whereas noncausative predicates will prototypically denote rapid, concrete activities, as in ModE divel 'to go into the water', the corresponding causative predicates will tend to indicate a lesser degree of concreteness in terms of dynamism and perceived activity, as in ModE dive2 'to cause to go into the water'. Moreover, many of the predicates that once belonged to the causative subdimensions of the most concrete domains (e.g. MOVEMENT, POSSESSION and PERCEPTION) tend to acquire the more abstract meanings of CAUSATIVE EXISTENCE, CAUSATIVE COGNITION or CAUSATIVE FEELING/EMOTION through metaphorical extension, so that:

15. The Modern High German expresion es gibt 'there is' (which occurs in the American English greeting what gives (with)? 'what happens') indicates the same relation between both domains. The inverse pattern (i.e. POSSESSION as EXISTENCE) is found in the Finnish idiom minulla on 'I have' (literally 'there is something to me'). 


\begin{tabular}{|l|c|}
\hline \multicolumn{1}{|c|}{ [+CONCRETE] } & [+ABSTRACT] \\
\hline $\begin{array}{l}\text { non-causative MOVEMENT } \\
\text { (e.g. to move) }\end{array}$ & (1) causative MOVEMENT \\
& (e.g. to cause to move) \\
& (2) causative FEELING \\
(e.g. to cause to feel moved )
\end{tabular}

Table 4: Verbs of MOVEMENT and FEELING: direction of semantic change (intra- and interfield extension).

I will argue now that this change in a verb's degree of concreteness as a consequence of its diachronic expansion from non-causation to causation runs parallel to the modification of the original predicate's syntax, so that whereas the verbs in the non-causative subdomains are simple syntactic units (corresponding to the nuclear pattern $\mathrm{V}$, as in OE déaf 'he dove'), OE morphological causatives imply the cooccurrence of $\mathrm{O}$ and $\mathrm{V}$ in the same lexical unit (as in OE dyfde 'diving (NP:O) caused (V) he' > 'he dived'). The change V > OV implies thus a gain in syntactic complexity, which reflects the loss of concreteness that is inherent to causation.

Sincronically speaking, the grammaticalization of the IE verb */ei/ in OE causatives implies that the syntactic complexity that was inherent to the primitive IE periphrases has been transformed into lexical and phonological complexity (as in OE déaf $\leq$ dýfde); however, this process did not necessarily imply a loss of the syntactic differences between non-causation and causation, which continued to be expressed with the transitive pattern OV (where O corresponds to the participant on which the change of state/possition takes place, as in he the boat sank > ModE he sank the boat). This transitive pattern can appear with the different $\mathrm{OE}$ causative predicates included in the lexical domains of MOVEMENT, LIGHT and PERCEPTION. However, the OE causative predicates of POSSESSION, FEELING and COGNITION analyzed here show a relatively high degree of optionality regarding the number and the nature of the arguments they can appear with, whereas causation is hardly ever expressed with the OV pattern in the subdomains of EXISTENCE and EMOTION. I will now present a brief analysis of the different complementation patterns that can be found in OE for all these predicates. My main aim here consists in determining how speakers convey different degrees of causation, and how these degrees correspond to a perfectly structured cognitive hierarchization.

\subsection{Basic causation: The OV/SVO pattern}

The previously mentioned OV pattern (as well as the 'newer' $\mathrm{SVO}^{16}$ ) is used to express the different causative subdimensions of MOVEMENT, LIGHT,

16. The grammaticalization of SVO word order in the history of English has been studied by, among others, Fries (1940), Lehmann (1972: 242-244) and Bean (1983). Statistic approaches have shown that the 
POSSESSION, PERCEPTION, FEELING and COGNITION. In the first three cases, causation is necessarily understood as a two-place action, through which ' $\mathrm{X}$ causes $\mathrm{Y}$ to MOVE/to BRIGHT', whereas causative POSSESSION (as expressed by the OE predicate sellan < Gmc */s $\alpha$ lj $\alpha \mathrm{n} /$ ' $\mathrm{X}$ causes Y to HAVE Z') requires the participation of three different arguments ${ }^{17}$.

Verbs of PERCEPTION, FEELING and COGNITION make reference to the bodily experience of the individual speaker. According to our lexical evidence, the primitive OV pattern is best interpreted as ' $\mathrm{X}$ causes $\mathrm{Y}$ (a part of his body) to move', as can be seen from the original IE periphrasis */pe:1-ei-o:/ 'I touch' (Gmc*/fo:ljo:/ > OE féle) and */leubh-eie-dhe:-si/ 'you loved' (Gmc *lußójdés > OE lufodest):

\begin{tabular}{|c|c|c|c|}
\hline \multicolumn{4}{|c|}{ IE *pe:1-ei-o: } \\
\hline pe:1 & ei & o: & \\
\hline skin & cause to move & $1 \mathrm{SG}$ & \\
\hline \multicolumn{4}{|c|}{ 'I touch' } \\
\hline \multicolumn{4}{|c|}{ IE *leubh-eie-dhe:-si } \\
\hline leubh & eie & dhe: & si \\
\hline liver & cause to move & did & 2SG \\
\hline
\end{tabular}

Differently to verbs of MOVEMENT, the grammaticalization of IE */ei/ and the subsequent change from $\mathrm{OV}$ to $\mathrm{V}$ contributed to the creation of new intransitive uses of these verbs (such as he hears), where the original causative meaning has been completely overshadowed by the new predicate's syntax.

When the roles of experiencer and phenomenon are made explicit (as in he heard $a \mathrm{dog}$ ), these are respectively expressed in nominative, which is the typically mover case (i.e. 'he who causes an organ of his own body to move'; Langacker 1991: 244) or undergoer/controller (van Valin and LaPolla1997: 544), and accusative, indicating the 'spatial extension' of the event of perception ${ }^{18}$.

old OV order was prevalent until $c 1200$ (Fries 1940: 201), especially in the case of dependent clauses (Díaz 1997: 28).

17. A variant of this SVO pattern, with O corresponding to an objective certain fact (realized as a subordinate sentence, as in He heard that her mother was arriving), was possible with OE causatives of PERCEPTION, FEELING, COGNITION and, less frequently, POSSESSION (Elmer 1981: 41-43).

18. The existence of a strong diachronic relationship between PERCEPTION (both sensorial and mental) and MOVEMENT is best exemplified by Finnish, where the ellative case (i.e. 'out of-N') is used to mark the experiencer of causative predicates of PERCEPTION (Karlsson 1982: 131), as in the following sentence (Salmela et al. 1994: 85):

$\begin{array}{lcll}\begin{array}{l}\text { Äidistä } \\ \text { out of the mother-ELL }\end{array} & \begin{array}{l}\text { mansikka } \\ \text { strawberry-NOM }\end{array} & \begin{array}{l}\text { maistuu } \\ \text { causes to taste }\end{array} & \begin{array}{l}\text { ihanalta } \\ \text { deliciously }\end{array} \\ \text { 'The strawberry tastes delicious to the mother' } & \end{array}$




\subsection{Reflexive causation: The SVAdj pattern}

This second syntactic pattern, which corresponds to Elmer's 'type II' (1981: 7275 ) and to Fischer and van der Leek 'experiencer-subject' (1983: 357), implies that a human experiencer $(\mathrm{S})$ comes in contact with a quality of something or someone $(\mathrm{O})$. Most of the $\mathrm{OE}$ causatives that can appear with this pattern correspond to the domain of FEELING:

[28] Se moessepreost pass mannes ofhreow [lit. 'THE MASS-PRIEST WAS ASHAMED OF THE MAN'; O3 NN_BIL_AELIVES26,III,142].

[29] ...biddende miltsunge be pam pe he mihte, \& behydde his swipran hand ofsceamod [lit. '...PRAYING WITH PITY BY WHAT HE COULD, AND CONCEALED HIS RIGHT HAND ASHAMED'; O3/4_IR_RELT_LSIGEW,67].

[30] Ic lustfullede pare stowe swetnesse [lit. 'I ENJOYED THE SWEETNESS OF THE PLACE'; O2_NN_HIST_BEDEHE,432].

The use of the genitive in these sentences (corresponding to the function of partitive, the quality or 'part of a whole' the experiencer perceives) is justified by the fact that, differently to verbs expressing PERCEPTION and COGNITION (which were formed by derivation from words that were originally used to name different parts of the human body: ears, stomach, mind, trunk, etc), the nouns that gave origin to these causative verbs of FEELING correspond to such abstract entities as shame, grieve or joy, none of which has a correspondence in the physical world. This implies that direct physical contact with the source of the feeling is not possible, so that its existence can be experienced only 'partially'19.

\subsection{Indirect causation: The OVS pattern}

A third personal pattern existed in $\mathrm{OE}$, which was characterized by the presence of a cause in nominative and an experiencer in dative (Elmer's 'type I', 1981: 70; Fischer and van der Leek's 'cause subject', 1983: 357), which, in spite of its grammatical role, is topicalized ${ }^{20}$ :

[31] Ealle pas ungesalpa us gelumpon purh unrodes [lit. 'ALL THESE MISFORTUNES HAPPENED TO US BECAUSE OF OUR FAULTS'; O3/4_NN_HIST_CHRONE,141].

[32] Sua eac Dauit, pe folneah on eallum pingum Gode licode [lit. 'So TOO DAVD, WHO PLEASED GOD IN EVERYTHING'; O2_IR_RELT_CP,35].

19. Non-physical contact is necessarily less complete than physical contact, and it is precisely this idea of partiality that the genitive case expresses here (corresponding to the partitive, as in Finnish säälin häntä 'I am sorry for him'; Karlsson 1982:107).

20. Another subtype of OVS, where S corresponds to a subordinate sentence (objective certain fact; see Elmer 1981: 21-30), can be found in OE. This pattern is especially productive with verbs of COGNITION (such as pyncan) and of COMING TO EXISTENCE (geweorpan, gelimpan). 
This pattern is used with predicates from the domains of FEELING, POSSESSION and EXISTENCE, and occurs whenever a verb assigns dative case to the experiencer and the cause remains unmarked. Cole (1986: 129-131) says that the dative case can function as a mark of 'secondary agent', i.e. someone who is responsible for furnishing the energy to initiate the process it undergoes (see further 3.4 bellow). This explains, among other things, why a predicate like OE lician, which requires a prototypically inanimate participant in the role of cause, universally conforms this pattern (Allen 1986: 404), or why OE scamian or lystan, where the notion of causation is strongly associated with the second participant, are not recorded in this form (Elmer 1981: 69).

This being so, the OVS pattern implies that the feeling, the possession, or the act of coming to existence resulted from some personality trait of the experiencer, rather than from a quality or action of the cause; moreover, this can be re-formulated in terms of moving and touching: physical contact between the two participants is not strictly necessary for the actual events expressed through the OVS pattern, and this fact is encoded in the neutral relation that the verb establishes with the second participant, which is not marked by any of the local cases that existed in OE.

\subsection{Resultative causation: the OVAdj pattern}

Finally, we find in OE the impersonal pattern OVAdj (Elmer 1981: 63-67; Fischer and van der Leek 1983: 357), where the verb assigns dative/accusative to the experiencer and genitive to the cause. This pattern is attested with causatives predicates from the different subdimensions of FEELING, but was apparently more frequent when the element 'experience pleasure' did not enter the predicate's definition (Elmer 1981: 65; Díaz 1998)²1:

[33] Her mag findan forebances gleaw, se pe hine lystep leopgiddunga [lit. 'HERE THE PRUDENT OF THOUGHT MAY FIND WHAT HE DESIRES OF SONGS'; OX/3_XX_XX_APOST,53].

[34] Mag pas ponne ofpyncan peodne Heapobeardna [lit. 'MAY THIS OFFEND THE TRIBE OF THE HEATHOBARDS'; OX/3_XX_XX_BEOW,63].

McCawley (1976: 194) and von Seefranz-Montag (1984: 524-525) state that these dative/accusative constructions imply lack of control or volition on the part of the experiencer22. However, Cole (1983) notes that the grammatical choice between

21. Negativity is often intensified by the OE prefix of, that almost always preceeds these predicates when used in OVAdj sentences (ofhreowan, ofpyncan, etc; Kastovsky 1992: 378).

22. This type of 'unvolitional' action with oblique experiencers is found in a wide range of IE and non-IE languages, such as Gothic, Russian, Rumanian, Bengali, Finnish, Hebrew or Japanese (see von Seefranz-Montag 1984: 524-525 for a complete list of bibliographical references). 
dative and accusative is not semantically neutral, as it indicates varying degrees of responsability in the activity on the part of the experiencer. As Langacker (1991: 257) puts it, "a pivot that fails to be marked as a secondary agent [i.e. in dative; see above] is simply a thematic object [...]. It undergoes a thematic process by externally-supplied energy, but is not specifically portrayed as controlling or initiating this process":

(a) SECONDARY AGENT

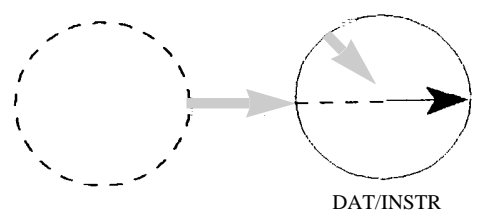

(b) THEMATIC OBJECT

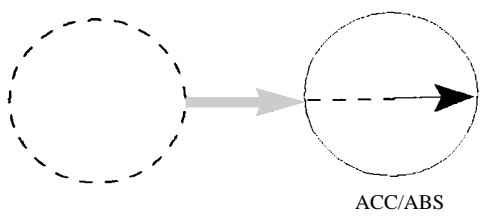

Figure 1: Semantic roles of DAT/INSTR and ACC/ABS in causative constructions (Langacker 1991: 257).

Given this semantic characterization of the OVAdj syntactic pattern, the reason why $\mathrm{OE}$ verbs of regret (i.e. predicates indicating the actuation of a negative feeling as the result of a wrong action of which experiencer makes himself responsible constitute) the most productive lexical category of impersonals becomes evident.

As we have seen here, OE etymological causatives constitute a special verbal category in the sense that they assign case to their arguments only optionally (Fischer and van der Leek 1983: 360). Case marking acts here as a lexically realized optional parameter (Pustejovsky 1995: 63-64; Faber and Mairal 1998b: 58), that speakers can use or not in order to express very refined semantic differences. These differences mainly affect the first argument of causative processes, that can acquire one of the following five semantic roles (Langacker 1991: 244):

(a) MOVER

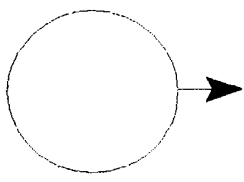

OV/SVO (b) ZERO

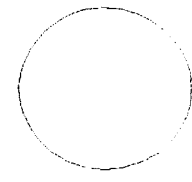

SVAdj (c) EXPERIENCER

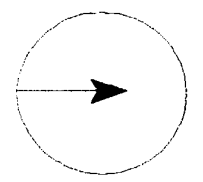

OVS (d) PATIENT

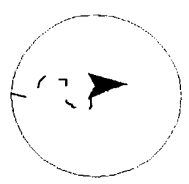

O (dat) VAdj (e) THEME

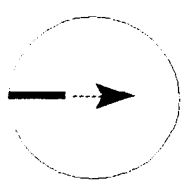

$\mathrm{O}(\mathrm{acc}) \mathrm{VAdj}$

Figure 2: Semantic and syntactic characterization of basic participants in causative processes. 


\section{Conclusion}

In this paper I have presented an analysis of a wide group of OE predicates that were formed as the result of the application of one of the following basic derivation patterns: (1) verb $+* / j \alpha /$, (2) noun $+* / j \alpha /$ and (3) ge- + verb. The etymological analysis of these three lexical patterns indicates that whereas types (1) and (2) were used to express 'causation as movement' (e.g. cause to MOVE an object, a bodily organ, a tract of personality), type (3) basically refers to processes of 'causation as possession' (i.e. cause to HAVE existence, light, need).

Moreover, the reconstruction of the different syntactic patterns each OE predicate can accept clearly indicates different degrees of involvement of the different participants in the causative process. Once again, this hierarchy of causative can be expressed in terms of movement and contact (both physical and, through metaphorical extension, abstract). According to my classification, to the most basic causative pattern OV/SVO (the ancestors of the ModE prototypical causative pattern SVO; Faber and Mairal 1998b: 56) corresponds the idea of complete direct contact (e.g. he sank the knife into the water, the janitor flashed the flashlight from the windows, both of them with specification of the concrete place where contact takes place), whereas OVS frequently implies lack of contact, so that the action is conceived by the speaker as 'taking place within the internal self of the individual' (the verb to like represents a prototypical instance of this type of situation, as the object of liking is not necessarily present in the process).

Moreover, I have argued that the SVAdj pattern represents an intermediate level of causation, where contact between the two participants is partial. Partial contact is indicated by two different facts: (1) all these verbs derive from nouns that made reference to completely abstract entities (namely feelings)with no counterpart in the physical world; and (2) the second participant appears in genitive, which is the case used to indicate partitive (as in ModE a cup of coffee).

\section{Works Cited}

AlLEN, CYNTHIA L. (1986) "Reconsidering the history of like". Journal of Linguistics 22: 375-409.

Bean, Marian C. (1983) The Development of Word Order Patterns in Old English. London: Croom Helm.

Bosworth, J. \& T.N. Toller. 1898. An Anglo-Saxon Dictionary. Oxford: Clarendon Press.

BRugmann, K. (1897-1916) Vergleichende Laut-, Stammbildungs- und Flexionsleher der Indogermanischen Sprachen. Strassburg: Trübner.

ByBEe, J. L. (1985) Morphology: A Study of the Relation between Meaning and Form. Amsterdam and Philadelphia: John Benjamins. 
THE DEVELOPMENT OF CAUSATION IN OLD ENGLISH AND ITS INTERACTION WITH LEXICAL

COLE, P. (1986) "The grammatical role of the causee in universal grammar". International Journal of American Linguistics 49: 115-133.

DíAZ, J. E. (1997) "Scribal attitutes towards syntactic change in late Old English and early Middle English". The Grove 3: 21-32.

DíAZ, J. E. (1998) "El concepto de iconicidad léxica en los procesos históricos: algunas implicaciones micro y macroestructurales”. In M.J. Feu and S. Molina (eds.) Estudios funcionales: léxico, traducción, sintaxis. Cuenca: UCLM, pp. 73-88.

ElMER, W. (1981) Diachronic grammar: the history of Old and Middle English subjectless constructions. Tübingen: Max Niemeyer.

FABER, P. \& R. MAIRAL (1998a) "Towards a typology of predicate schemata in a Functional-Lexematic Model". In G. Wotjak (ed.) Towards a Functional Lexicology. Frankfurt: Peter Lang. 11-37.

FABER, P. \& R. MAIRAL (1998b) "Towards a Semantic Syntax". Revista Canaria de Estudios Ingleses 36: 37-64.

FABER, P. \& Ch. PÉREZ (1993) "Image schemata and light: a study in contrastive domains in English and Spanish". Atlantis 15: 117-134.

FISCHER, O. \& F. VAN DER LEEK (1983) "The demise of the Old English impersonal construction". Journal of Linguistics 19: 337-368.

FRIES, Ch. (1940) "On the development of the structural use of word-order in Modern English". Language 16: 199-208.

Givón, T. (1979) On Understanding Grammar. New York: Academic Press.

Givón, T. (1984) Syntax: A Functional-Typological Introduction. Vol. 1. Amsterdam and Philadelphia: John Benjamins.

KARLSSON, F. (1982) Suomen peruskielioppi. Helsinki: SKS.

KAstovsKY, D. (1992) "Semantics and Vocabulary". In R. M. Hogg (ed.) The Cambridge History of the English Language I: The Beginnings to 1066. Cambridge: Cambridge University Press, pp. 290-408.

KYTÖ, M. (1996) Manual to the Diachronic Part of the Helsinki Corpus of English Texts: Coding Conventions and Lists of Source Texts (3rd ed.). Helsinki: Helsingin Yliopisto.

LANGACKER, R.W. (1987) Foundations of Cognitive Grammar I: Theoretical Prerequisites. Stanford: Stanford University Press.

LANGACKER, R.W. (1991) Concept, Image, and Symbol: The Cognitive Basis of Grammar. Berlin and New York: Mouton de Gruyter.

LASS, R. (1994) Old English: A Historical Linguistic Companion. Cambridge: Cambridge University Press.

LehmanN, W.P. (1972) "Proto-Germanic Syntax". In F. Van Coetsem and H.L. Kufner (eds.) Towards a Grammar of Proto-Germanic. Tübingen: Max Niemeyer, pp. 239-267. 
LIDDELL, H.G. \& R. SCOTT (1968) Greek-English Lexicon (9th edition). Oxford: Clarendon.

Lehmann, W.P. (1974) Proto-Indo-European Syntax. Austin: University of Texas.

MAIRAL, R. (1994) "Parámetros para la organización de una sintaxis léxica funcional". In J. Martín (ed.) Estudios de Gramática Funcional. Zaragoza: Servicio de Publicaciones de la Universidad de Zaragoza, pp. 23-63.

McCAWLEY, N. (1976) "From OE/ME 'impersonals' to 'personal' constructions: what is a 'subjectless' S". In C.A.Walker and S.S.Mufwene (eds.) Papers from the Parasession on Diachronic Syntax. Chicago: Chicago Linguistic Society, pp. 92-100.

NEDYALKOV, V.P. \& G.G. SiLNITSKY (1978) "The typology of morphological and lexical causatives”. In F. Kiefer (ed.) Trends in Soviet Theoretical Linguistics. Dordrecht and Boston: ICG, pp. 7-30.

LowE, P. (1972) “Germanic word formation". In F. van Coetsem and H.L. Kufner (eds.) Towards a Grammar of Proto-Germanic. Tübingen: Max Niemeyer, pp. 211-238.

PERrotT, D.V. (1987) Teach Yourself Swahili. London: Hodder and Stoughton.

POKORNY, J. (1959-69) Indogermanisches etymologisches Wörterbuch (2 vols.). Bern and Munich: Francke Verlag.

Pustejovsky, J. (1995) The Generative Lexicon. Cambridge (Mass.): The MIT Press.

SALMElA, A.L. et al. (1994) Suomea: Ole hyvää! Suomea aikuisille maahammuuttajille. Helsinki: Painatuskeskus Oy.

SEEFRANZ-MonTAG, A. (1984) “'Subjectless' constructions and syntactic change”. In J. Fisiak (ed.) Historical Syntax. Berlin: Mouton, pp. 521-553.

SIEVERS, E. (1899) Angelsäksische Grammatik. Halle: Max Niemeyer.

SOUTER, A. et al. (1968) The Oxford Latin Dictionary. Oxford: Clarendon.

SweETSER, E. (1990) From Etymology to Pragmatics: Metaphorical and Cultural Aspects of Semantic Structure. Cambridge: Cambridge University Press.

TOPS, G. (1978) "The origin of the Germanic dental preterite: von Friesen revisited". In J. Fisiak (ed.) Recent Developments in historical phonology. The Hague: Mouton de Gruyter, pp. 349-372.

VAn VAlin, R. D. \& R. J. LAPOLla (1997): Syntax. Structure, Meaning and Function. Cambridge: Cambridge University Press. 